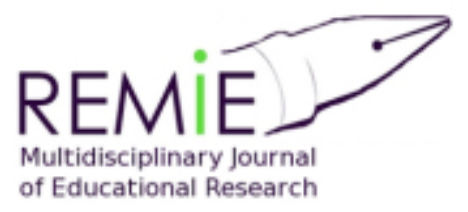

Instructions for authors, subscriptions and further details:

http://remie.hipatiapress.com

\title{
The Role of Emotional Intelligence in Bilingual Education: A Study on The Improvement of The Oral Language Skill
}

Cristina Morilla-García ${ }^{1}$

1) University of Cordoba. Spain

Date of publication: February $15^{\text {th }}, 2017$

Edition period: February 2017-June 2017

To cite this article: Morilla-García, C. (2017). The Role of Emotional Intelligence in Bilingual Education: A Study on The Improvement of The Oral Language Skill. Multidisciplinary Journal of Educational Research, 7(1), 2752. doi:10.17583/remie.2017.1840

To link this article: http://dx.doi.org/10.17583/remie.2017.1840

\section{PLEASE SCROLL DOWN FOR ARTICLE}

The terms and conditions of use are related to the Open Journal System and to Creative Commons Attribution License (CC-BY). 


\section{The Role of Emotional Intelligence in Bilingual Education: A Study on The Improvement of The Oral Language Skill}

Cristina Morilla-García

University of Córdoba

\section{Abstract}

The emotional dimension of learning can hinder or help to determine the success of the cognitive development of students in bilingual education settings. The objective of this study is to enquire how effectively the application of emotional intelligence is in the process of the acquisition of the oral skills in the foreign language at an early age, specifically in the first year of primary education. The findings obtained in this investigation proceed from a study in which we have analyzed and compared a bilingual educative programme that integrates the dimensions of emotional intelligence in its curriculum, AMCO, with other approaches in which this type of attention is not previously organized in their programs such as CLIL and the teaching of a foreign language. Eclectic research combining a qualitative and a quantitative methodology has been applied to control the oral variables. The results show that students who have been exposed to a methodology that integrates techniques for the application of emotional intelligence obtain better marks in the oral production of the L2 favouring its acquisition. Furthermore, the study found evidence that these students were more motivated in the process of speaking and showed more selfesteem, and self-control in the classroom interactions.

Keywords: bilingual education, emotional intelligence, oral skills, motivation, selfawareness, self-regulation 


\section{El Papel de la Inteligencia Emocional en la Enseñanza Bilingüe: Un Estudio sobre la Mejora de la Competencia Linguiística Oral}

Cristina Morilla-García

University of Córdoba

\section{Resumen}

La dimensión emocional del aprendizaje puede obstaculizar o ayudar a determinar el éxito del desarrollo cognoscitivo del alumno en entornos de bilingüismo educativo. El objetivo de esta investigación es indagar en el grado de efectividad que la aplicación de la inteligencia emocional tiene en el proceso de aprendizaje de la competencia oral de la L2 en edades tempranas, específicamente en el primer año de educación primaria. Los hallazgos obtenidos proceden de un estudio comparativo entre un tipo de enfoque metodológico particular para centros bilingües, AMCO, que cuenta como una de sus características principales la atención al trabajo diferenciado de acuerdo con la inteligencia emocional, con otros enfoques en los que este tipo de atención no se produce de manera previamente planificada y organizada: CLIL y la enseñanza de lenguas extranjeras. Se ha aplicado un enfoque ecléctico en el que se ha combinado una metodología cuantitativa y cualitativa. Los resultados muestran que los estudiantes que han estado expuestos a una metodología que integra técnicas para la aplicación de la inteligencia emocional obtienen mejores notas en la producción oral de la L2 favoreciendo su adquisición. Asimismo, se ha constatado en esta investigación que estos estudiantes estaban más motivados en el proceso de comunicación oral y mostraron más autoestima y autocontrol en las interacciones en el aula.

Palabras clave: educación bilingüe, inteligencia emocional, destrezas orales, motivación, autoconciencia, autorregulación 


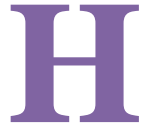

uman learning does not occur in isolation, in other words it is not linked exclusively to cognitive factors; emotions and learning are related. Social and emotional factors are fundamental in the process of acquiring a foreign language. Kramsch (1990) states that the complexity that can arise in the language classroom is not a consequence of the complexity involved in the study of a foreign language exclusively, but to other factors arising within the learning group like insecurity, lack of experience, lack of memory and emotional issues. Sometimes these factors are invisible and complex like attitudes of attraction or rejection and feelings of dependency. Learning a foreign language is a process that provokes anxiety in students (Horwitz et al., 1986), specifically if they are anxious about their ability to produce the L 2 in oral situations in the class, which leads to a type of anxiety termed according to MacIntyre \& Gardner (1991) communication apprehension. Thompson \& Lee (2013, p. 747) also bring light to several issues regarding to language learning classroom anxiety and their findings provide evidence that "language proficiency has a profound effect on language anxiety". Based on recent research, Goleman (1995) highlights the importance of emotions in personal and professional life and explains the role of alternative forms of intelligence relegated until now to the world of education and work, where knowledge and intellectual skills have dominated for decades. Arnold (2011) also support that affective issues are indeed a very central part of language teaching. These aforementioned studies provided the main frame for this research in which the aim is to investigate the process of teaching and learning foreign languages in response to psychopedagogical issues that help to improve the deficiencies in the oral skills of students in schools. Particularly those obtained from the research concerning emotional intelligence (Goleman, 1995; Greenspan, 1989; Ledoux, 1986; Payne, 1985; Salovey \& Mayers, 1990; Stenberg 1997). The objective of this research is to examine whether the application of emotional intelligence through specific strategies integrated into the curriculum is more effective in learning the L2 oral skills in the classroom. This analysis investigates different methodological approaches in various educational contexts such as the bilingual program AMCO characterized by including the dimensions of emotional intelligence in its curriculum (Goleman, 1995) CLIL model/CLIL/ÉMILE whose central idea is "the 
integration of language and content in the L2" (Marsh, 1994, p. 23; Short, 1991, p. 1).

\section{Emotional Intelligence in Bilingual Education}

Emotions and thoughts, passions and intelligence coexist in the capacity of learning everything around us. Goleman (1998) describes knowledge of neurophysiology of the brain in the theory of emotional intelligence. He defines the term emotional intelligence as the ability to recognize our own feelings and those of others, for motivating and managing emotions well in ourselves and in our relationships. According to Arnold and Brown (1999), the inability to dissociate cognition and affection is an undeniable fact. Similarly, Bless \& Fiedler (2006) state that empirical evidence shows that affect has a direct influence on cognition. Emotional intelligence is related to the harmonious functioning between "emotional and intellectual centres" (Goleman, 1998, p. 430). In the field of bilingual education students require a greater effort to assimilate the contents in the foreign language. Problem solving is part of this process so that students are exposed to some level of anxiety. It is for this reason that "emotional intelligence is essential to stimulate L2 learning and especially for obtaining achievements for the ability to interact in the classroom" (Pavón \& Ávila, 2009, p. 91), interaction in a bilingual context requires personal and social competence.

\section{Influence of Personal Competence in the Development of Oral Skills}

In the foreign language classroom, it is necessary to promote the identification of feelings and behaviour so that students can control their own emotions, strengths, weaknesses, needs and drives and be able to motivate themselves and to handle most successful interpersonal relationships (Goleman, 1998). According to Lawrence (1997, p. 357), teaching children to understand and communicate their emotions will influence many aspects of their development and success in later life. In the first year of primary education, students acquire the necessary language and the ability to express themselves, the ability to show emotional awareness and the ability to talk about feelings in the foreign language. This ability depends on the teacher's 
proficiency to interact with students and to ensure that they interact with each other accurately on the school context. Proper evaluation of oneself, in the sense of knowing one's own strengths and weaknesses, is very important for the development of oral proficiency in L2. Self-consciousness awakens talent and energy for the production of sentences and for the interaction with teachers and peers. Goleman (1998, p. 91) states that "self-awareness gives us an accurate compass to align our decisions with our deepest values" and describes the dimension of self-control as the ability to adequately manage emotions and conflicting impulses. MacIntyre, Noels and Clément (1997, p. 280) found a correlation of high level of anxiety with low scores of selfrating questionnaires of second language proficiency. Their findings supported the important role that self- perceptions play in anxiety and in achievement: "Self-perceptions of language competence are not isomorphic with measured proficiency; affective factors may help cause the discrepancy. To help students to enhance this dimension we can use some resources to help to control these negative emotions. Among these, the reconsideration and the isolation from the focus of conflict in order to obtain serenity or distraction are highlighted. Techniques like self-relaxation, deep breathing or meditation can also help. These resources are also useful in case students suffer anxiety when they must face conversation or present content in a foreign language in the classroom.

Other competences of self-regulation are, the reliability to cope with changes and achieving innovation so that students feel comfortable with new ideas, approaches and information presented in class L2. Students who are gifted with these skills are able to control their feelings and impulses and are able to create an atmosphere of trust. Those who manage to master their emotions can handle these changes. If this emotional stability is achieved, numerous advantages are obtained. Students will not panic when new contents are introduced and they will be able to present information orally with a greater degree of attention, involvement and fluency. In education, the classroom environment should be positive enabling the students to be more receptive to new initiatives proposed by the teachers increasing oral productivity.

Firstly, motivation is the dimension that allows students to develop without being affected by an external negative mental state and that goals and 
expectations are set to achieve premeditated success. Goleman (1998) describes three basic motivational skills: commitment, achievement and optimism.

Commitment is the ability to tune in with the objectives of an organization or group and comes from emotional attachment. This competence occurs in people willing to sacrifice something for the benefit of the group. Initiative and commitment make students feel compelled to seize opportunities and face the adversities that arise in the classroom. Moreover, achievement is the impulse that drives us to improve or "meet" a model of excellence. Gifted students in this competence struggle to get the results that have been set and are motivated to meet its objectives. They seek creative challenges and are willing to face them above their own and others' expectations. They are motivated by the need for achievement and are interested in learning, they gather the necessary information and properly consolidate it to improve the level of performance. For the learning of oral skills in the L2 where information processing is done via the target language, student motivation may be affected until the level of communicative competence between student-teacher is fluid yet students in bilingual education are likely to do the job well done and have unlimited energy to perform tasks in which they feel they are involved due to the fact activities focused on the content in L2 are highly motivating.

Finally, optimism is the way we interpret setbacks, always looking for positive, non- defeating responses. It occurs in people who understand their failures as an opportunity to do better in the future. Optimism and hope are closely linked: "Hope is a motivating force whose absence leads to paralysis" (Goleman, 1998, p. 184).

\section{Influence of Social Competence in the Development of Oral Skills of L2}

Empathy is defined as the ability to know and understand what the other person feels, their perspective and their emotions. On this premise empathy is essential to make oral representations requiring a personal relationship with peers in the classroom. Empathy requires understanding of others and this is an essential competence for the educator who must capture the feelings and views of the students. This will allow them to anticipate, recognize and 
meet the needs of their students and act accordingly to the diversity that they face, thus developing what Goleman (1998, p. 212) calls "the competence of service orientation".

Other skills of empathy include the ability to recognize and reward the strength of others. Among the components of empathy, we emphasize its importance in the development of oral competence of the L2; leveraging of diversity. This competence is based on three fundamental skills: having a good relationship with different people, appreciating the uniqueness of others and not missing any opportunity that could provide us this situation (Goleman, 1998, p. 221).

According to Lawrence (1997, p. 89), "the reward for teaching children to show more empathy is huge." Children who show a great capacity for empathy tend to be less aggressive and collaborate with actions involving participation and sharing. As children grow, their perceptual and cognitive abilities mature and they learn to recognize the different types of emotional distress and develop appropriate behaviour, Lawrence (1997) says that empathy is the basis of all social skills.

For students in the foreign language classroom to be more empathetic, caring and helpful, we should instill a sense of responsibility through consistent standards, for example, maintaining order and cleanliness in the class, making each student responsible for different tasks arising daily in the classroom, teaching them to practice random acts of kindness, encouraging them to help others through projects, tutoring younger children, preparing presentations on English culture, etc. Social skills are what allow us to interact in a healthy and positive way and receive responses in the L2. Our moods are easily transmitted through vital signs. They are powerful messages that are not only articulated with words. It is a signaling system based on emotions that can influence the emotional state of others positively or negatively. Positive feelings lead us to create a better working climate favouring equality, cooperation, collaboration and leads to better performance of the group that is critical to the learning process of oral proficiency in the L2.

Goleman (1998) cites several powers to describe the social ability to mobilize the emotions of others: influence and persuasion. One of the strategies used is delegating tasks to people who have networks of influence 


\section{Morilla-García-Emotional Intelligence in Bilingual Education}

and seek support. Communication is another competition that exists in the art of listening that is, to remain receptive, understand, formulate appropriate questions, being open to difficult issues and giving convincing messages. The mood is also important: the neutral mood is the best; emotional control allows us to be open to what we are told and accurately respond to conflicts that may arise. We should note that in the communication of words, according to Lawrence (1997), it actually represents only a part of emotional communication:

In a series of studies, psychologist Albert Mehrabian showed that in face-to-face interactions, 55 percent of emotional meaning of a message is expressed through non-verbal cues such as facial expression, posture and gesture, and 38 percent is transmitted through tone of voice. Only 7 percent of emotional meaning is expressed through words (p. 369).

Nonverbal behaviour is continuous, in contrast to the verbal behaviour in L2 that starts and stops. Children are always communicating through body language and facial expressions, being consciously or unconsciously. Our knowledge of the rules of nonverbal behaviour lies in the emotional parts of our brain which are out of reach of our cognitive understanding "available for analysis when we recognize the importance of this type of communication" (Lawrence, 1997, p. 371). In the foreign language classroom, understanding the power of nonverbal communication by teachers can help students to develop skills in leadership, self-confidence and to be able to show empathy for the needs and problems of their peers.

Finally, Goleman emphasizes the conflict resolution that is the ability to negotiate and resolve conflicts, collaboration, cooperation and team skills. According to Lawrence (1997, p. 239), many children who have problems in getting along with others lack the ability to talk and are not able to convey their needs to other children. By contrast, according to Goleman (1998, p. 246), children who are gifted with this intelligence handle relationships with others and tense situations with diplomacy, they recognize potential conflicts, encourage debates and open discussions and seek solutions that can satisfy everyone. In the foreign language classroom, where students interact, solutions should be provided in order to avoid tense relationships between them and foster a suitable atmosphere for learning through the interpretation 
of signs to prevent conflicts and to refrain from giving threats or demands. Lawrence (1997, p. 272) states that one of the pillars a child needs to consolidate social relationships is the ability to join a group of the same sex. It is at the age of six, at the beginning of primary education, when children begin to appreciate that being a member of a group can improve their confidence and the sense of belonging.

It is for this reason that you must select the right people to integrate emotions in cognitive dimensions and get the full potential of students in the development of their learning of oral skills in the L2. Carpena (2010, pp. 5152) argues that their knowledge and their practice has led to important personal skills and ensures that educational action will be meaningless if we limit ourselves to the learning of a series of techniques and if they are not accompanied by an emotional reflection and connection that validates and leads not only to individual fulfilment but to a collective fulfillment.

\section{Models for the Process of the Acquisition of the Oral Skills of the Foreign Language}

In this study, we have analyzed different bilingual programs in different educational contexts, AMCO and CLIL. We have also included in the methodological comparison the teaching of the foreign language in a nonbilingual context.

\section{AMCO}

The bilingual education programme AMCO extends from pre-primary to secondary education. This programme is implemented in Mexico with headquarters in San Diego (CA, USA), from which comes the different materials and educational resources. Subsequently it has spread to several countries in America such as Chile, Colombia, El Salvador and Nicaragua. In the year 2007/2008, AMCO International Educational Services Co. decided to expand in Europe, starting with the selection of some schools in Spain.

The AMCO bilingual programme is based on the assumption that all human beings possess all the intelligences and these are not set in stone but 


\section{Morilla-García-Emotional Intelligence in Bilingual Education}

educable, they can be developed (Gardner, 1983). The theory of emotional intelligence (Goleman, 1995) occupies a privileged place in the AMCO methodology and interestingly, it is integrated in an organized and sequenced manner. Thus, in the AMCO classroom numerous strategies in foreign language are made to enhance the five dimensions of emotional intelligence. The first dimension is self-awareness. Different strategies are provided so that teachers make learners to be aware of the processes involved in learning the L2. The teachers are provided with techniques that help students developing self-awareness and gaining control of the interactive conversations in the L2. On the basis of the existing research, the significance of individual learner's and the development of the learner's directiveness has been enhanced (Holec, 1981; Sinclair et al., 1999). Self- awareness helps students to interact better and communicate more effectively when producing statements in the L2.

The second dimension of emotional coefficient "self-control" is also integrated in AMCO through resources provided to the teachers. In the classes in which the L2 is taught reactions may occur, such as anxiety (Horwitz, 1986; Scovel, 1978), depression or anger, even interfering in learning, and causing, in this way, inadequate classroom situations. In the AMCO bilingual programme teachers are trained to identify feelings and behaviour that encourages students so that they can control their own emotions and are able to manage most successful relationships.

Thirdly, self-motivation is worked, which allows students to develop without being affected by external negative mental states, self-motivation also permits them to set goals and expectations to achieve premeditated success. Concerning motivation in the second language acquisition, there is a strong correlation between motivation and language learning (Masgoret \& Gardner, 2003). According to Dörnyei (2009, p. 217) the initial motivation to learn a language does not come from internally or externally generated self-images but rather from successful engagement with the actual language, learning process. In his proposal, namely the 'L2 Motivational Self System Dörnyei (2005) recognizes the importance of the different components of the classroom: the teacher, the curriculum and the learner group. 
Heras \& Lasagabaster (2015, p. 15) point out that several quantitative research studies have been made to validate the L2 Motivational Self System in different learning environments.

The fourth dimension is empathy, that according to Brown (2000) is the ability to understand or feel what other understand or feel and it in context where a second language is taught is a significant skill. In AMCO methodology this premise is essential to make oral presentations or dialogues in the classroom and to improve the fluidity of the speech in L2. In the fifth dimension relationship skills are formed, also known as social skills, and they are what allows us to interact in a healthy and positive way.

\section{CLIL}

The second bilingual programme selected for the investigation has been CLIL (AICLE, by its acronym in Spanish). There are diverse and complex factors that favour a change in the education system. Marsh (2013, pp. 130131) argues, based on Moujaes et al. (2012), that in this transformation there are important keys to keep in mind, as the recognition that the demand of a change needs an immediate response. The educational response to multilingual education by the European Commission (Marsh, 1994) is CLIL (Content and Language Integrated Learning). There is general consciousness that we should focus on an education based on the needs of the learner.

This bilingual programme is based on the assumption that the learning of contents of different non-linguistic and linguistic subjects are promoted at the same time, there is not "fusion", there is an "integration", in which academic knowledge is transmitted in a foreign language. It is a "dualfocused educational approach" (Coyle, Hood \& Marsh, 2010, p. 1), in which students learn different content areas through the foreign language and improve the language proficiency (Marsh \& Lange, 2000).

The perspective of the integration of language and content in the L2 in the classroom involves the work of topics from cultures of the target language which is used as a vehicle for learning in different tasks with the aim of "engaging student's participation and interaction" (Dalton -Puffer, Nikula \& Smith, 2010, p. 1). 
These discussions promote an enabling environment for meaningful learning and social context and helps the student to think in the second language, this fact contributes to a better cognitive and cultural development. According to Casal (2011, p. 96) the first two pillars, being "cultural and social contexts" reflect the sociocultural theory of Vygotsky (1978). The next two pillars which are "language and content" lead to the development of a natural environment where content that is related to academic disciplines is the organizing element of the teaching unit.

Affective factors are important in CLIL methodology, however emotional intelligence is not integrated into the learning curriculum as in AMCO methodology. CLIL bilingual programme helps to make the learning process more meaningful and less stressful due to much greater exposure to the L2, students show less stress and anxiety as it focus not only on language forms but on meaning and communication (Heras \& Lasagabaster, 2015) and the students feel more motivated.

\section{Teaching English as a Foreign Language}

Teaching English as a foreign language is based on the approach of traditional teaching encompassing a series of concepts related to the transmission of knowledge that the teacher instils in the students using the L1 and the translation to the L2. The fact of not being exposed to the L2 in the English classroom is one of the reasons for the deficit we have found in Spain in the mastery of a second language in oral communicative skills.

The traditional methodology is characterized by the excessive weight of the rational element, the knowledge is based primarily on linguistic intelligence and logical-mathematical intelligence. The teacher follows a unidirectional and non-participatory methodology and has no opportunity for interaction in the classroom. The instructions are often given in the L1 which requires visual, spatial, kinaesthetic, musical, intrapersonal and interpersonal support. Classes are not dynamic. The objectives and contents are not treated in a coordinated way and the schedules are used for working in isolation, hardly coordinating with other teachers. 


\section{Research Design}

\section{Objectives and Research Questions}

The general objective of this research is to investigate, through the comparative analysis of different educational proposals, the effectiveness of the methodological principles which favour the acquisition of communicative competence in the classroom, especially those related to emotional intelligence. To do so, a comparative study has been made of a methodological approach AMCO used in bilingual schools. In the curriculum, the five dimensions of emotional intelligence with other contexts in which it is not produced in a pre- planned and organized way is integrated, namely the bilingual education model CLIL and the teaching of the L2 following a traditional methodology. This research has been carried out in different educational centres in which the aforementioned methodologies are taught in primary education, specifically in the first year.

As specific objects, we evaluate the importance of the integration of the emotional intelligence responding to the following research questions:

1. Does the bilingual education program that integrates emotional intelligence in the curriculum stimulate the development of oral language skills?

2. Is there a clear difference in the level of the oral production depending on the methodology used?

3. Students who have been exposed to a bilingual educational program, in which strategies are applied to enhance emotional intelligence, are they more motivated and do they develop self-esteem and self-control when they state L2 oral messages?

\section{Context and Participants}

This study has looked into three different approaches of learning oral skills in the foreign language, two of them are programs of bilingual education and the other is the teaching of the second language in a traditional manner. It has been considered that the number of subjects of the sample taken is not a very large number. It is, therefore, a homogeneous group of students exposed to 
the learning of English through different programmes. Considering that we are engaged in an educational context, groups are natural groups, the sample comprises from fifteen to thirty students, formed according to the criteria of the centre. In this quasi- experimental design, the profile of the subject of this study is outlined with the intention that the internal and external validity is not seriously affected.

This research was carried out in the first course of primary education with A1 level of English of the Common European Framework of Reference for Languages (CEFR) in the following centres: Colon school (Córdoba) in which the CLIL bilingual program is implemented, Salesian School (Montilla) with AMCO bilingual program and Saint Joseph school (Montilla) that follows the regular or traditional teaching of English as a foreign language.

\section{Procedure and Data Gathering}

In this research, an eclectic approach has been used. We have applied a quantitative paradigm but we have also relied on a qualitative paradigm whose main purpose, according to Bisquerra (1989, p. 66), is "to describe a phenomenon". Data collection took place during the second quarter of $2008 / 2009$. This process has been developed in several phases. The first phase of the experimental treatment consisted of the collection of test data based on oral production tests from Trinity College. Planning for data collection was needed two sessions with each group.

In the second phase, we proceeded to the classroom observation. There has been three sessions for each group in which special attention has been paid to the methodology taught in the classroom.

The variable oral skill refers to the value of the domain of a conversation in which students show, based on an exchange of questions and answers, in grades 1 and 2 of the Trinity exams, approved by the Common European Framework Reference for Languages of the Council of Europe (CEFR).

Scoring criteria respond to the following parameters:

- A-Distinction. Includes 4 errors or less.

- B-Merit. It comprising 4 to 8 errors.

- C-Pass. It contains 8 to 12 errors. 
REMIE-Multidisciplinary Journal of Educational Research, 7(1) 41

- D-Fail. Con 13 or over thirteen errors.

\section{Results}

The following bar charts and sectors feature the results of the oral variable studied for each school separately.

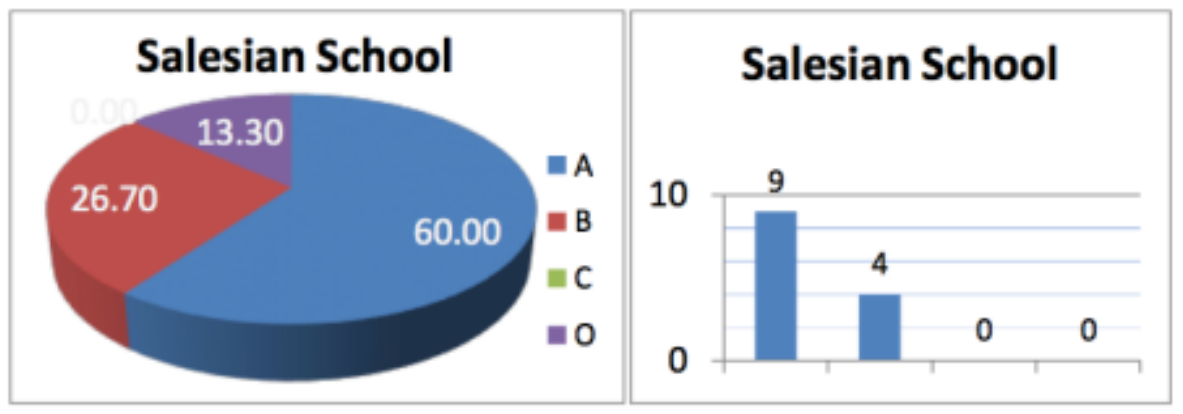

Figure 1. Variable oral skills. Salesian School

Figure 1 shows the oral results of the Salesian centre where the bilingual programme AMCO methodology integrates the five dimensions of the emotional intelligence into the $\mathrm{L} 2$ learning curriculum. The oral skills of the students in the first year at this school have positive marks, $60 \%$ have obtained an A which is the highest score "distinction", a 25.7\% have obtained a B "merit" and $13.3 \%$ has been lost value. This data indicates that most of the students who have followed this program, based on the integration of emotional intelligence, have a high proficiency level in the oral skill. The majority of students using AMCO's methodology have demonstrated the ability to exchange greetings and to understand simple instructions using short answers, and the level of the group is homogeneous. Concerning the interaction in English the students have answered simple questions, they have proved to be able to provide personal information to describe objects, humans and animals and to use the vocabulary and grammar suggested in the A1 level of the CEFRs. With respect to their feelings in the oral test they have never felt embarrassed when providing key information and they were highly 
motivated. Confirming a previous research study, "promoting emotional intelligence practices in the curriculum can enhance the learning of an L2, and lower the affective barriers which might impede L2 oral production" $(\mathrm{Oz}$, H., 2014, p. 429).

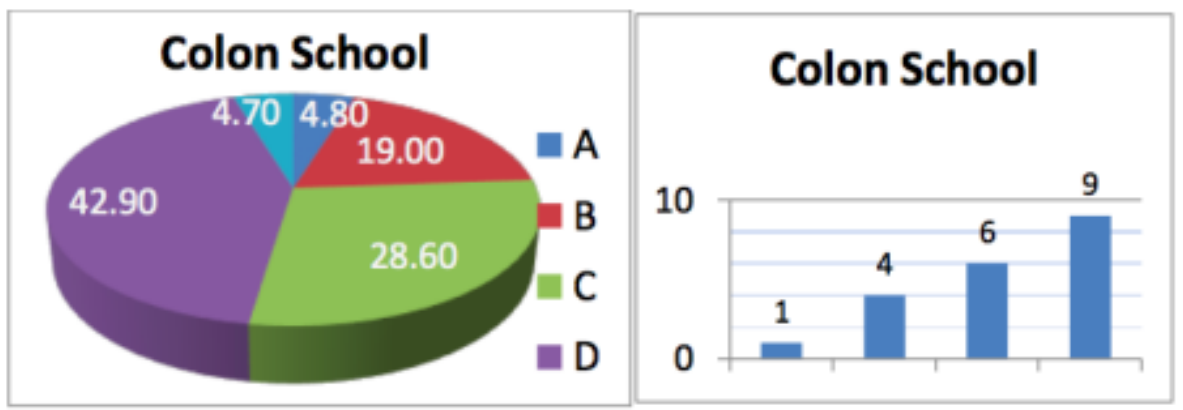

Figure 2. Variable oral skills. Colon School

At the Colon school, where CLIL methodology is implemented the results show that a $42.9 \%$ of the students have not been able to produce the L2 in the exchange of questions and answers proposed in the initial level, they obtained a D which is a "fail" in the oral exam. Among the students who passed the tests, 28.6 obtained a C being a "pass", 19\%, obtained a B "merit" and 4.8 obtained an A "distinction". Results in CLIL group reveal that results are not homogeneous.

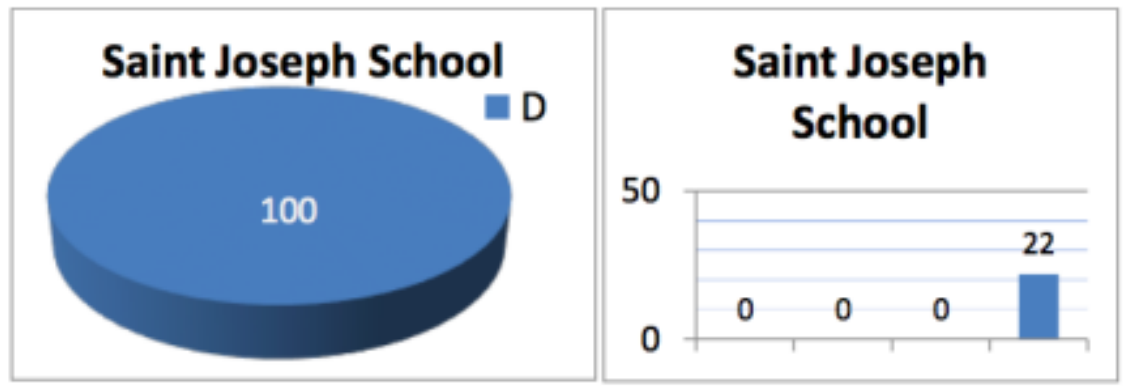

Figure 3. Variable oral skills. Saint Joseph School (Insert Figure 3) 
The results of the bar and pie chart obtained in Saint Joseph indicate that $100 \%$ of students lack communication skills in the L2. This data shows that students following the traditional approach of learning English as a foreign language have unsatisfactory results in oral production. Learners have not been able to answer simple questions, instructions to act, perform interactive descriptions and to provide personal information. They have shown inaccuracies when describing objects, people or animals and have been unable to use the vocabulary and grammar appropriate for the A1 level. The teacher is the sole agent in the classroom and the students play a passive, receptive attitude, which is counterproductive to develop classroom interaction between teacher-student and peer interaction in the L2. There is a lack of social ability to mobilize the emotions for the learning of the L2.

Table 1.

Percentage of valid data

\begin{tabular}{|c|c|c|c|c|c|c|}
\hline Schools & & Frequency & & $\begin{array}{c}\text { Percent } \\
(\%)\end{array}$ & $\begin{array}{c}\text { Valid } \\
\text { percent }(\%)\end{array}$ & $\begin{array}{l}\text { Cumulative } \\
\text { percent }(\%)\end{array}$ \\
\hline \multirow[t]{5}{*}{ Salesian school } & Valid & 9 & A & 60,00 & 69,20 & 69,20 \\
\hline & & 4 & $\mathrm{~B}$ & 26,70 & 30,80 & 100,00 \\
\hline & & 0 & $\mathrm{C}$ & 0,00 & 0,00 & 0,00 \\
\hline & Missing & 2 & $\mathrm{O}$ & 13,30 & 0,00 & 0,00 \\
\hline & Total & & & 100,00 & 0,00 & 0,00 \\
\hline \multirow[t]{6}{*}{ Colon school } & & 1 & A & 4,80 & 5,00 & 5,00 \\
\hline & & 4 & $\mathrm{~B}$ & 19,00 & 20,00 & 25,00 \\
\hline & & 6 & $\mathrm{C}$ & 28,60 & 30,00 & 55,00 \\
\hline & & 9 & $\mathrm{D}$ & 42,90 & 45,00 & 100,00 \\
\hline & Missing & 1 & $\mathrm{O}$ & 4,70 & 100,00 & \\
\hline & Total & & & 100,00 & 100,00 & \\
\hline Saint Joseph school & Valid & 22 & $\mathrm{D}$ & 100,00 & 100,00 & 100,00 \\
\hline
\end{tabular}


As shown in the frequency table in the Salesian School where the AMCO methodology is implemented, the results of the oral examination are high and homogeneous, that is to say that the notes of the students do not differ from each other in a relevant way. If we consider the valid percentage, $69.2 \%$ of students who took the tests have passed with the highest score and $30.8 \%$ of the group obtained B in these tests.

As for the results of the Colon school, in which the CLIL methodology is used, we can appreciate that the results are inferior and more heterogeneous to those obtained in the school where the AMCO methodology is implemented. They show that a valid percentage of $5 \%$ of students passed the test with an A, $20 \%$ passed the test with a B, $45 \%$ with a C and $30 \%$ of the students obtained a D.

Finally, the results of the oral examination, in Saint Joseph School, where English is taught as a foreign in a traditional way, $100 \%$ of students failed the oral exam, $100 \%$ of the group obtained a $\mathrm{D}$ in the valid percentage results.

Figure 4 exhibits data synthesizing a contrast of the results of the three centres.

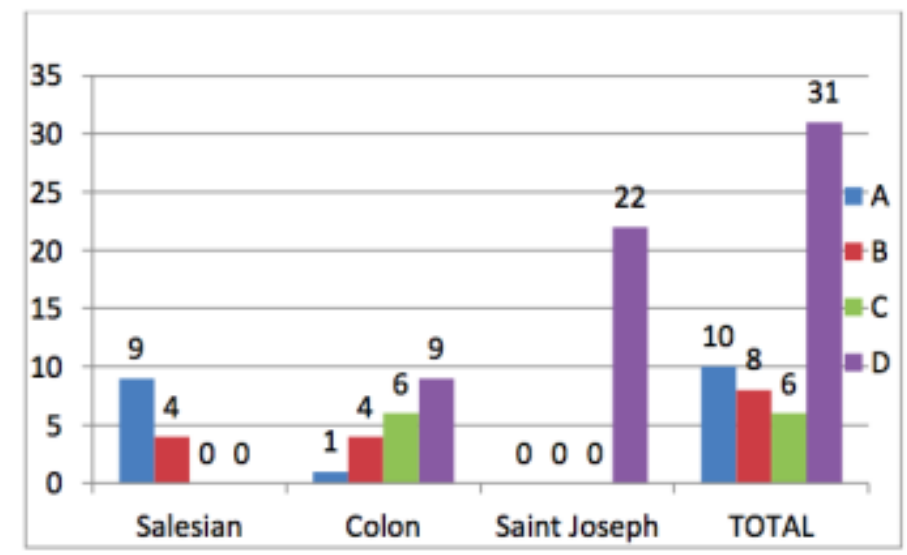

Figure 4. Global study of the schools 
Table 2.

Contrast of the results of the three schools with valid data

\begin{tabular}{llllll} 
& & \multicolumn{2}{l}{ School } & & \\
\cline { 3 - 4 } & & & & \\
Salesian & & San José & \\
ORAL & A & 9 & Colon School & School & Total \\
EXAM & B & 4 & 1 & 0 & 10 \\
& C & 0 & 4 & 0 & 8 \\
& D & 0 & 6 & 0 & 6 \\
Total & & 13 & 20 & 22 & 31 \\
& & & & 22 & 55
\end{tabular}

The present study investigates the potential correlation between the integration of the emotional intelligence in a methodology and the student's proficiency in oral skills. Table 2 shows an overall score for a better interpretation of the oral test data presented below in which only valid data is studied. Students from the Salesian school, in which the AMCO methodology is implemented integrating the multiple intelligences in an organized way have acquired a higher score on the oral tests with grades of $\mathrm{A} / \mathrm{B}$ and an average mark of 8.2 , followed by those students have been exposed to the CLIL methodology in the Colon school with an overall score of $\mathrm{B} / \mathrm{C}$ whose average is 7 and finally the students exposed to the traditional methodology based solely on logical-mathematical intelligence at the Saint Joseph school have obtained an overall score of $\mathrm{D}$ with an average grade of 4.5 are higher in the school where the AMCO methodology is taught than in the schools where the CLIL and the traditional methodology is provided.

As indicated in figure 4 and table 2 the results obtained in this research are significant. The findings obtained in oral production variables in different educational centres allow us to answer the first research question. In this we refer to whether the methodology that integrates emotional intelligence in its planning stimulates the development of oral language skills. In conclusion of the study conducted in the first course of primary education, we find that the 
results obtained with the $\mathrm{AMCO}$ bilingual programme, that integrates emotional intelligence in bilingual education, were higher than in the centres where the traditional and CLIL methodologies were taught. In teaching children, specifically in the primary stage, the methodology focuses on the skills of logical reasoning and factual knowledge, which are the most direct indicators in educational success. However, Immordino-Yang and Damasio (2007, p. 9) explain that there are two problems with this approach. Firstly, they allude to the fact that learning does not only occur in the purely rational domain (divorced from emotion), but our knowledge is manifested in a moderately rational, not emotional way. Secondly they state that, to teach students to minimize the emotional aspects of their academic curriculum and to work as much as possible in the rational domain, educators might be encouraging students to develop the kind of knowledge that is not properly transferred to real-world situations.

Regarding the second research question in which we investigate whether there is a clear difference in the level of oral production depending on the methodology used. On the basis of the results the difference is obvious. Data from the evidence regarding oral skills from students subjected to the teaching of English, as a foreign language is proof that they are below average and they are not able to hold a basic conversation adapted to their level. Students exposed to CLIL methodology in which flexible linguistic immersion or translanguaging (Garcia, 2009, p. 45) is used, passed the test. The results of this methodology in the oral skills were much higher compared to the teaching of English as a foreign language. Finally, in our study, the bilingual programme AMCO adopts total immersion by the switching process, students do not use the L2 in the classroom and it is a process similar to the L1 learning. English language is acquired without allowing translation in the classroom, it is based on the multiple intelligence strategies that allow the student to obtain information through various channels in the classroom. In bilingual education, teaching is based on the integration of content and language learning, it involves teaching programmes that must be built on a common basic structure: "basic information, title of the unit, cross-cutting themes, aims, objectives, content and sequencing of the unit, design and sequencing of activities, evaluation, materials and bibliography (Pavón, 2007, p. 56). In traditional methods, the structure is not very dynamic. 
Concerning motivation, self-esteem and self-control when producing oral messages in the L2 we investigated the third research question by incorporating classroom observations into the study. We have noticed that the use of streamlined emotional intelligence instructions in the L2, leads to increased self-esteem and motivation. The findings from the present study suggest that the results of the learner's proficiency oral skill in CLIL methodology would improve integrating emotional intelligence into L2 learning curriculum.

\section{Conclusion}

In this study, we have investigated the role of emotional intelligence in bilingual education. The overall objective was to investigate, the effectiveness of the application of emotional intelligence in the communicative competence of the L2 classroom. For this purpose, an investigation has been conducted in primary education that has contrasting bilingual programmes in which the focus of emotional intelligence and its application in the classroom is different.

According to Lawrence (1997, p. 357) teaching children to understand and communicate their emotions will influence many aspects of their development and success. Carpena (2010, p. 52) believes that all aspects of the primary stage must be programmed, such as learning to relax and techniques to help students learn how to manage their emotions. All of this will result in an interactive class where students can express themselves in the L2 without difficulty and are motivated to participate in tasks proposed by the teacher. Goleman (1998, p. 47) states that emotional intelligence determines the potential capability that we have to learn practical skills and is based on self-awareness, self-control, empathy and relationship skills, all of which will determine more effective communication. In line with the above, we highlight that the majority of the processes by which educators are concerned, including memory, learning and creativity, involving both cognitive and emotional aspects. Cognition and emotion according to Immordino-Yang and Fischer (2010, p. 313) are two sides of the same coin. Damasio (1998, p. 1999) explains that basic emotions like anger, fear, 
happiness and sadness, are cognitive processes that involve the mind and body.

Teaching children to understand and communicate their emotions in the classroom influences many aspects of development (Lawrence, 1997, p. 357). In the classroom where emotions were integrated, students worked in a relaxed environment suitable for learning. We observed how the oral presentations by cooperative learning enhanced self-esteem and motivation and these dimensions of the emotional intelligence ensured better performance for the benefit of the group. They enjoyed the learning process, showed participation and diminished the complexity that according to Kramsch (1990, p. 30) is involved with the learning of a foreign language such as "insecurity, lack of experience or memory and especially, affective factors".

In light of the results obtained in this research, we estimate that the emotional dimension contributes positively to the process of learning a foreign language. According to Immordino- Yang and Damasio (2007, p. 9) "emotions, thoughts and feelings have a huge impact on how to consolidate and use knowledge". A proper application of the emotional dimensions in the classroom improves the teaching of the two principles that, according to Cameron (2001, pp. 107-122) govern the development of the oral skills: the significance and participation in the oral discourse and the development of knowledge and skills in order to interact in the foreign language classroom. This supports the findings of $\mathrm{Oz}(2015$, p. 428) that suggests that "the ability to recognize one's emotions and others' emotions, and the ability to control and regulate these emotions play a key role in fostering enhanced L2 communication among EFL learners". With these considerations, we are aware that the integration of the emotional intelligence in learning contexts of L2 oral proficiency is needed in education.

In the process of research and classroom observation we have met with moral limitations because in the schools where the research was conducted, recording the sessions was not allowed for issues of privacy. Concerning possible lines of future research, an experimental approach could be used to investigate the contribution of emotional intelligence in the acquisition of non-language areas in bilingual education. 
REMIE -Multidisciplinary Journal of Educational Research, 7(1) 49

\section{References}

Arnold. J., \& Brown, H.D. (1999). A map of the terrain. In J. Arnold (Ed.) Affect in Language Learning (pp. 1-24). Cambridge: Cambridge University Press.

Arnold, J. (2011). Attention to Affect in Language Learning. Anglistik. International Journal of English Studies, 22(1),11-22.

Bless, H., \& Fiedler, K. (2006). Mood and the regulation of information processing and behavior. In J. P. Forgas (Ed.), Hearts and minds: Affective influences on social cognition and behaviour (pp. 65-84).

New York, NY: Psychology Press.

Bisquerra, R. (1989). Métodos de investigación educativa. Barcelona: Ceac.

Brown, D. H. (2000). Principles of language learning \& teaching. New York: Longman.

Cameron, D. (2001). Working with Spoken Discourse. Londres: Sage. Carpena, A. (2010). Desarrollo de las competencias emocionales en el marco escolar. CEE. Participación Educativa, 15, 40-57. Retrieved from http://www.mecd.gob.es/revista-cee/pdf/n15-carpenacasajuana.pdf

Casal, S. (2011). Bases teóricas y metodológicas en AICLE. In S. Casal (Ed.), Implicaciones de la Enseñanza Bilingüe en centros Educativos (pp. 95-104). Archidona: Aljibe,

Council of Europe. (2006). Eurydice Report. Brussels: European Comission. Retrieved from http://www.eurydice.org/

Coyle, D., Hood P., \& Marsh, D. (2010). Content and Language Integrated Learning. Cambridge: Cambridge University Press.

Dalton-Puffer, C., Nikula, T., \& Smit, U. (Eds.) (2010). Language use and language learning in CLIL classrooms. Amsterdam, Netherlands: John Benjamins.

Damasio, A. R. (1998). Investigating the biology of consciousness. Philosophical Transactions of the Royal Society London, Section B, 353, 1879-1882. doi: 10.1098/rstb.1998.0339

Dörnyei, Z. (2005). The psychology of the language learner: Individual differences in second language acquisition. Mahwah, NJ: Lawrence Erlbaum. 
50 Morilla-García-Emotional Intelligence in Bilingual Education

Dörnyei, Z. (2009). The L2 motivational self-system. In Z. Dörnyei \& E. Ushioda (Eds.), Motivation, language identity and the L2 self (pp. 942). Bristol, England: Multilingual Matters.

García, O. (2009). Bilingual Education in the 21st Century: A Global

Perspective. West Sussex, UK: Wiley-Blackwell.

Gardner, H. (1983). Frames of Mind: The Theory of Multiple Intelligences. New York: Basic Books.

Goleman, D. (1995). Emotional Intelligence. Nueva York: Bantam Books. Goleman, D. (1998). La práctica de la inteligencia emocional. Barcelona: Kairós.

Greenspan, S. I. (1989). Emotional intelligence. In K. Field, B. J. Cohler, G. Wool (Eds.), Learning and Education: Psychoanalytic perspectives (pp. 209-243). Madison, CT: International Universities Press.

Heras, A., \& Lasagabaster, D. (2015). The impact of CLIL on affective factors and vocabulary learning. Language Teaching Research, 19, 70-88. doi: 10.1177/1362168814541736

Holec, H. (1981). Autonomy and Foreign Language Learning. Oxford: Pergamon.

Horwitz, E. K., M. B. Horwitz, \& J. A. Cope. (1986). Foreign language classroom anxiety. Modern Language Journal, 70, 125-132. doi: 10.1111/j.1540-4781.1986.tb05256.X

Immordino-Yang, M. H., \& Damasio, A. R. (2007). We feel, therefore we learn: the relevance of affective and social neuroscience to education. Mind, Brain, and Education 1(1), 3- 10. doi: 10.1111/j.1751228X.2007.00004.X

Immordino-Yang, M. H., \& Fischer, K.W. (2010). Neuroscience bases of learning. In V. G. Aukrust (Ed.), International Encyclopedia of Education, 3rd Edition. (pp. 310-316) Oxford: Elsevier.

Kramsch, C. (1990). The order of discourse in language teaching. In B.

Freed (Ed.), Foreign Language Acquisition Research and the Classroom (pp. 191-204). Lexington, MA: D.C. Heath, Teacher's Edition of Textbook.

Lawrence E. (1997). La inteligencia emocional de los niños. Buenos Aires: Vergara. 
REMIE-Multidisciplinary Journal of Educational Research, 7(1) 51

LeDoux, J. E. (1986). The neurobiology of emotion. In J.E. LeDoux, W. Hirst (Eds.), Mind and Brain: Dialogues in Cognitive Neuroscience (pp. 301-354). Cambridge: Cambridge University Press.

MacIntyre, P. D. \& Gardner, R. (1991). Language Anxiety: It's

Relationship to Other Anxieties and to Processing in Native and Second Languages. Language Learning, 41, 513 - 534. doi:

10.1111/j.1467-1770.1991.tb00691.x

MacIntyre, P. D., Noels, K. A., \& Clément, R. (1997). Biases in self-ratings of second language proficiency: The role of language anxiety.

Language Learning, 47, 265- 287. doi: 10.1111/0023-8333.81997008

Masgoret, A. M., \& Gardner, R. C. (2003). Attitudes Motivation, and

Second Language Learning: A Meta-Analysis of Studies Conducted

by Gardner and Associates, Language Learning, 167-21. doi:

10.1111/1467-9922.00227

Marsh, D. (1994). Bilingual Education and Content and Language

Integrated Learning. International Association for Cross-cultural

Communication. Language Teaching in the Member States of the European Union (Lingua). Paris: University of Sorbonne.

Marsh, D. (2013). The CLIL Trajectory: Educational Innovation for the

21st Century Generation. Córdoba: University of Córdoba Academic Press.

Marsh, D., \& Langé, G. (2000). Using Languages to Learn and Learning to Use Languages. Jyväskylä: University of Jyväskylä.

Moujaes, C., Hoteit, L., Hiltunen, J., Sahlberg, P. (2012). Transforming

Leadership in Education: Three Key Imperatives. Booz \& Company: Abu Dhabi.

Oz, H. (2015). Emotional Intelligence as a Predictor of L2

Communication. Procedia-Social and Behavioral Sciences, 186, 424430. doi: 10.1016/j.sbspro.2015.04.117

Payne, W. L. (1985). A study of emotion: developing emotional intelligence; self-integration; relating to fear, pain and desire (theory, structure of reality, problem solving, contraction/expansion, tuning in/coming out/letting go). A Doctoral Dissertation. Cincinnati, $\mathrm{OH}$ : The Union for Experimenting Colleges and Universities. 
Pavón, V. (2007). La implantación de la enseñanza plurilingüe en Andalucía: hacia una nueva propuesta metodológica y curricular. Perspectiva CEP,13, 45-60. Sevilla: Consejería de Educación de la Junta de Andalucía.

Pavón, V., \& Ávila, J. (Eds.). (2009). Aplicaciones didácticas para la enseñanza integrada de lengua y contenidos (AICLE/CLIL/ÉMILE). Sevilla: Consejería de Educación de la Junta de AndalucíaUniversidad de Córdoba.

Salovey, P., \& Mayer J. D. (1990). Emotional intelligence. Imagination, Cognition, and Personality, 9, 185-211. doi: 10.2190/DUGG-P24E52WK-6CDG

Sinclair, B., McGrath, I., \& Lamb, T. (Eds.). (2000). Learner autonomy, teacher autonomy: Future directions. London: Longman.

Scovel, T. (1978). The effect of affect on foreign language learning: A review of the anxiety research. Language Learning, 28(1), 129-142. doi: 10.1111/j.1467-1770.1978.tb00309.x

Short, D. J. (1991). How to integrate language and content instruction: A training manual. Washington, DC: Center for Applied Linguistics.

Short, D. J. (1993). Assessing integrated language and content instruction. TESOL Quaterly, 27(4), 627-656. doi: 10.2307/3587399

Sternberg, R. J. (1997). Successful Intelligence. Nueva York: Plume. Thompson, A. S., \& Lee, J. (2013). Anxiety and EFL: Does multilingualism matter? International Journal of Bilingual Education and Bilingualism, 16, 730-749. doi: 10.1080/13670050.2012.713322 Vygotsky, L. (1978). Mind in society: The Development of Higher Psychological Processes. Cambridge: Harvard University Press.

Cristina Morilla-García is researcher at the Department of English and German Philology, University of Córdoba, Spain.

Contact Address: Plaza Cardenal Salazar, 3, 14003 Córdoba. E-mail: cristmogar@hotmail.com 